\title{
Caterpillar-Specific Gene Expression in the Legume, Medicago truncatula
}

\author{
Shireef A. Darwish • Li Pan • Christine Ide • \\ Jacqueline C. Bede
}

Published online: 4 March 2008

(C) Springer-Verlag 2008

\begin{abstract}
Plants adjust their defense responses to target caterpillar herbivores. Their ability to do this is, in part, based on the recognition of salivary elicitors which are secreted during insect feeding. We are interested in identifying caterpillar-specific defense responses in the model legume, Medicago truncatula Gaertn. (Fabaceae). To do this, we have taken advantage of the fact that labial salivary secretions of caterpillars of the beet armyworm, Spodoptera exigua Hübner (Lepidoptera: Noctuidae), can be impaired by cauterizing the spinneret. Plant tissues were removed within $1 \mathrm{~h}$ after the initiation of herbivory, and differentially expressed transcripts were identified by cDNA-amplified fragment length polymorphism (cDNA-AFLP). Gene expression patterns of five differentially expressed transcripts and one constitutive gene were verified by quantitative real time-polymerase chain reaction (qRT-PCR). Genes encoding ribulose-1,5-bisphosphate carboxylase/oxygenase activase (rubisco activase; $M t R C A)$, strictosidine synthase (MtSTR), an unknown protein (MtUNK), a zinc RING finger protein $(M t R F P)$, and a receptor-like protein kinase $(M t R P K)$ were constitutively expressed. In plants subject to mechanical damage or herbivory by caterpillars, lower expression of MtRCA, MtSTR, Mt UNK, and MtRFP was observed. In comparison, higher levels of $M t R P K$ were expressed in a caterpillar-specific manner.
\end{abstract}

Keywords Caterpillar-cDNA-AFLP. Gene expression · Legume · Medicago truncatula $\cdot$ Spodoptera exigua
Abbreviations
Cat
caterpillars with impaired or intact salivary secretions
Caut caterpillars with impaired salivary secretions
cDNA-AFLP complimentary DNA-amplified fragment length polymorphism
Intact
GOX caterpillars with intact salivary secretions glucose oxidase

\footnotetext{
S. A. Darwish $\cdot$ L. Pan $\cdot$ C. Ide $\cdot$ J. C. Bede $(\triangle)$

Department of Plant Science, McGill University, 21,111 Lakeshore, Ste-Anne-de-Bellevue,

QC, Canada H9X 3V9

e-mail: jacqueline.bede@mcgill.ca

Springer
} 


$\begin{array}{ll}\text { PCR } & \text { polymerase chain reaction } \\ M t E F & \text { gene encoding elongation factor } \\ M t R C A & \text { gene encoding rubsico activase } \\ M t R C A & \text { gene encoding rubsico activase } \\ M t R F P & \text { gene encoding a zinc finger transcription factor } \\ M t R P K & \text { gene encoding a receptor-like protein kinase } \\ M t S T R & \text { gene encoding strictosidine synthase } \\ M t U N K & \text { gene encoding an unknown protein } \\ \text { qRT-PCR } & \text { quantitative real time-PCR } \\ \text { wnd } & \text { wound }\end{array}$

\section{Introduction}

For a plant to respond appropriately to biotic attack, perception of the stress and targeting plant defenses against the herbivore or pathogen is critical (Kessler and Baldwin 2002; Kessler and Halitschke 2007; Walling 2000). General induced responses to chewing herbivores, such as caterpillars, are primarily mediated by octadecanoid hormones, such as jasmonic acid; however, other phytohormones such as ethylene and abscisic acid are also important regulators, and growing evidence suggests the involvement of auxin and nitric oxide (Ferry et al. 2004; Gatehouse 2002; Hermsmeier et al. 2001; Schilmiller and Howe 2005; Zhu-Salzman et al. 2005). These signaling pathways form complex interconnected networks through signaling nodes which fine-tune the plants' defense response against the caterpillar herbivore. Plant responses are initiated after the perception of herbivory through signals such as oligogalacturonides released from the cell wall which result in electric signaling and calcium influxes and a rapidly induced, transient production of reactive oxygen species (Léon et al. 2001; Maffei et al. 2007; Ryan 1994). Further specificity of plant defenses against the herbivore are achieved through the integration of plant responses to caterpillar signals, such as footsteps or elicitors present in the insect oral secretions (Hall et al. 2004; Kessler and Baldwin 2002). Particularly, semiochemicals secreted in the oral secretions of phytophagous insects have been shown to participate in the plants' recognition of specific pests (Alborn et al. 1997; Musser et al. 2002).

As they feed, caterpillars use oral secretions to transport the ground leaf tissues into their mouthparts. These oral secretions, which include regurgitant and labial and mandibular saliva, contain a milieu of potential elicitors that are recognized by the plant and shape its defense response. Treatment of wounded corn seedlings with volicitin, which is found in caterpillar regurgitant, induces the synthesis and release of volatiles that lure predators or parasitoids of the herbivorous caterpillar to the plant and/or act to prime plant defenses (Alborn et al. 1997; Engelberth et al. 2004; Kessler and Baldwin 2001; Turlings et al. 2000; von Dahl et al. 2006; von Dahl et al. 2007). Labial saliva contain a number of enzymes, such as glucose oxidase (GOX), lysozyme, and ascorbate peroxidase (Eichenseer et al. 1999; Liu et al. 2004; Mathews et al. 1997; Merkx-Jacques and Bede 2005), which function to initiate digestion, detoxify noxious plant chemicals, or may be antimicrobial. In addition, GOX may be a caterpillar mechanism to circumvent induced plant defenses (Bede et al. 2006; Musser et al. 2002). 
GOX catalyzes the oxidation of glucose to produce gluconic acid and hydrogen peroxide $\left(\mathrm{H}_{2} \mathrm{O}_{2}\right)$. Depending on the temporal and spatial levels in the plant, the signaling molecule $\mathrm{H}_{2} \mathrm{O}_{2}$ may act as an upstream signal for phytohormone biosynthesis, such as ethylene, or activation of proteins, such as NPR1, which may result in the attenuation of defense-related, octadecanoid-dependent responses (Chamnongpol et al. 1998; McGrath et al. 2005; Mou et al. 2003; Pieterse and van Loon 2004; Thines et al. 2007). Also, this antimicrobial agent may serve to protect the caterpillar against pathogens present on the leaf surface (Eichenseer et al. 1999; Musser et al. 2005b). Caterpillar salivary GOX gene expression and enzyme activity is affected by the diet the insect is feeding upon (Bede, unpublished data, (MerkxJacques and Bede 2005; Peiffer and Felton 2005). When protein intake is sufficient, GOX activity correlates to the glucose content of the diet. Caterpillar development, survival, and later, adult fecundity are greatly impacted by the nutritional intake of the larval instars. Consequently, salivary GOX may be a mechanism for caterpillars to cope with excess dietary carbohydrates by metabolizing glucose to gluconate, which is not metabolized by the insect (Babic et al. 2008).

Therefore, salivary GOX may be a mechanism for caterpillars to undermine plant defense responses by interfering with octadecanoid-dependent induced defenses (Musser et al. 2002, 2005a); however, enzyme activity reflects the nutritional quality of the plant diet (Babic et al. 2008; Merkx-Jacques and Bede 2005; Peiffer and Felton 2005). Given this intricate balance between the plant and its herbivorous caterpillar, the goal of this study is to understand the role of salivary elicitors, which include GOX and other enzymes, in the transcriptional regulation of plant defense responses. The robust differential display technique cDNA polymorphism (cDNAAFLP) was used to identify caterpillar-specific gene expression in plants which is mediated by salivary elicitors.

Six-week-old Medicago truncatula Gaertn. plants were subjected to herbivory by fourth instar caterpillars of the beet armyworm, Spodoptera exigua Hübner (Lepidoptera: Noctuidae). M. truncatula is a diploid relative of the agriculturally important forage crop alfalfa (M. sativa) and has become established as a tractable model for studying legume biology (Cannon et al. 2005; Town 2006). The beet armyworm is a generalist agricultural pest in Asia and southern parts of North America (Azidah and Sofian-Azirun 2006; Greenberg et al. 2001). To identify caterpillar-specific gene expression, herbivory by caterpillars with normal salivary functions was compared to caterpillars which had their spinnerets cauterized, thereby preventing salivary secretions. Expression of five genes, which were identified by cDNA-amplified fragment length polymorphism (cDNA-AFLP), were verified by quantitative real time-polymerase chain reaction (qRT-PCR).

\section{Materials and Methods}

\section{Medicago truncatula}

Seeds of M. truncatula cv Jemalong were scarified in sulfuric acid (15 min) to break dormancy and sown in pasteurized soil. Plants were watered with one sixth dilution of 20:20:20 NPK three times per week and grown in environmental growth 
chambers $\left(22^{\circ} \mathrm{C}, 260 \mu \mathrm{Em}^{-2} \mathrm{~s}^{-1}, 16 \mathrm{~h}\right.$ light, and $8 \mathrm{~h}$ dark $)$. At 5 weeks, plants were repotted and transferred to the greenhouse for 1 week. Plants were kept in large plastic bins which were covered with a mesh cloth to provide additional protection against any pests present in the greenhouse.

\section{Spodoptera exigua}

S. exigua eggs were obtained from the GAST Insect Rearing Facility (Stoneville, Mississippi), and caterpillars were reared on an artificial wheat germ-based diet (Bio-Serv), in a growth chamber (16:8 light/dark hours; 28 to 40\% relative humidity; $28.5^{\circ} \mathrm{C}$ ). Fourth instar $S$. exigua larvae were used in the herbivory experiments. Caterpillars were raised on artificial diet, but transferred to "feeder" M. truncatula plants for approximately $24 \mathrm{~h}$ before the experiments.

\section{Spinneret Ablation and Detection of Salivary Glucose Oxidase}

To allow comparison between salivary-specific and general plant responses, one group of caterpillars had their spinnerets cauterized shut with a hot needle, inhibiting labial salivation while not affecting their feeding behavior (Bede et al. 2006). Early fourthinstar caterpillars were cooled on ice and placed under a stereomicroscope. The spinneret was cauterized with a hot metal probe (Musser et al. 2002). Immediately after cauterization, caterpillars were placed on artificial diet and allowed to recover for $3-5 \mathrm{~h}$. The success of cauterization was tested using a horseradish peroxidase (HrP)-o-diaminobenzidine (DAB)-coupled reaction (Bergmeyer 1974). Caterpillars were allowed to feed for approximately $2 \mathrm{~h}$ on Whatman $21 \mathrm{~mm}$ diameter glass microfiber filter discs (Fisher Scientific) moistened with $300 \mu$ glucose:sucrose solution $(1: 1,50 \mathrm{mg} / \mathrm{ml}$ of each, Sigma). Discs chewed by the caterpillars were treated with $150 \mu \mathrm{l}$ of 3,3'-diaminobanzidine tetrahycrochloride $(1 \mathrm{mg} / \mathrm{ml}, \mathrm{pH} 5.8$, Sigma) and $150 \mu$ horseradish peroxidase $(2.5 \mathrm{U}$ in $50 \mathrm{mM}$ potassium phosphate buffer, $\mathrm{pH}$ 7.0, Sigma). The presence of salivary GOX was indicated by a dark brown precipitate.

\section{Greenhouse Experiment}

Plants were spatially segregated in treatment groups on the greenhouse bench to avoid the potential influence of airborne volatile signals on gene transcription. Plants were subject to one of four treatments: undamaged (ctl), wounding (wnd), herbivory by caterpillars with intact (cat), or impaired salivary secretions (caut). Mechanically wounded plants were cut in a circular pattern with scissors, but not across the leaf midvein, to mimic caterpillar herbivory. In insect-treated plants, four caterpillars were applied to each plant. S. exigua feed on plants most frequently during the night; therefore, these experiments were conducted at 2100 hours. Thirty and $60 \mathrm{~min}$ after the initiation of treatments, leaflets were rapidly separated into local (L) if they had been wounded, while undamaged leaflets adjacent on the same trifoliate were considered systemic (S) and immediately frozen in liquid nitrogen and stored at $-80^{\circ} \mathrm{C}$. The entire trifoliate was collected from control plants. Four to five plants were pooled for each sample, and the experiment was repeated at least two times. 
RNA Isolation and cDNA Synthesis

Total RNA was extracted from $100 \mathrm{mg}$ of M. truncatula leaves, after grinding in liquid nitrogen, using RNAqueous kit (Ambion) according to the manufacturer's instructions. This was followed by isolation of poly $(\mathrm{A})^{+}$-RNA using the mTRAP kit (Active Motif). This method uses an oligo d(T)-peptide nucleic acid to capture the polyadenylated RNA. Manufacturer's protocol was followed. First strand cDNA synthesis was prepared using the Reflectase Reverse Transcriptase kit (Active Motif). To the first stand reaction, the following was added: $91 \mu \mathrm{l}$ DEPC-treated water, $30 \mu \mathrm{l} 5 \times$ second strand buffer, $0.2 \mathrm{mM}$ dNTP mix (New England Biolabs), $10 \mathrm{U}$ E. coli DNA ligase, $2 \mathrm{U}$ E. coli DNA polymerase I, $2 \mathrm{U}$ ribonuclease $\mathrm{H}$. Enzymes, and second strand buffer were purchased from Invitrogen. The reaction was incubated at $16^{\circ} \mathrm{C}$ for $2 \mathrm{~h}$ in a thermocycler, followed by the addition of $10 \mathrm{U}$ T4 DNA polymerase and incubation at $16^{\circ} \mathrm{C}$ for $5 \mathrm{~min}$. The reaction was placed on ice and terminated with the addition of $10 \mu \mathrm{l}$ ethylenediaminetetraacetic acid (EDTA) (0.5 M, pH 8). A non-template control was included in all these manipulations.

\section{cDNA-Amplified Fragment Length Polymorphism}

cDNA-amplified fragment length polymorphism (cDNA-AFLP) analysis was performed according to Bachem et al. (1998). cDNA (250 ng) was mixed with $20 \mathrm{U}$ of the endonuclease Taq I (LiCor Bioscience) and incubated at $65^{\circ} \mathrm{C}$ for $2 \mathrm{~h}$, followed by digestion with $20 \mathrm{U}$ of Mse I endonuclease (LiCor Bioschience) and incubation at $37^{\circ} \mathrm{C}$ for $2 \mathrm{~h}$. Endonucleases were inactivated by incubating for $20 \mathrm{~min}$ at $80^{\circ} \mathrm{C}$. Digested cDNA was mixed with equimolar amounts of Taq I and Mse I adapters, which were complementary to the overhangs generated by endonuclease digestion (Table 1). Samples were denatured by heating to $65^{\circ} \mathrm{C}$ and cooled gradually to room temperature to allow annealing of complimentary strands and then incubated with $1 \mathrm{U} \mathrm{T} 4 \mathrm{DNA}$ ligase at $20^{\circ} \mathrm{C}$ for $2 \mathrm{~h}$ to generate the primary cDNAAFLP template.

A 5- to $10-\mu$ l aliquot of the primary template was amplified by PCR using oligonucleotide primers complimentary to the ligated adapters (Table 1). The PCR program used was as follows: 20 cycles: $94^{\circ} \mathrm{C}, 30 \mathrm{~s} ; 56^{\circ} \mathrm{C}, 1 \mathrm{~min} ; 72^{\circ} \mathrm{C}, 1 \mathrm{~min}$. The resulting PCR product (secondary template) was visualized on a $1 \%$ agarose gel and showed a visible smear between 50 and $500 \mathrm{bp}$. This secondary template was diluted 1:10 with DEPC-treated $\mathrm{H}_{2} \mathrm{O}$ and stored at $-20^{\circ} \mathrm{C}$.

The secondary template was re-amplified by PCR using two selective base extensions at the $3^{\prime}$ end of the Taq I and Mse I primers. Taq I selective primers were labeled with a 700-nm infrared dye (LI-COR Biosciences). The PCR program used was as follows: 12 cycles: $94^{\circ} \mathrm{C}, 30 \mathrm{~s} ; 65^{\circ} \mathrm{C}\left[-0.7^{\circ} \mathrm{C} /\right.$ cycle $], 30 \mathrm{~s} ; 72^{\circ} \mathrm{C}, 1 \mathrm{~min}$ and 30 cycles: $94^{\circ} \mathrm{C}, 30 \mathrm{~s} ; 56^{\circ} \mathrm{C}, 30 \mathrm{~s} ; 72^{\circ} \mathrm{C}, 1 \mathrm{~min}$. A negative control containing all PCR reagents except secondary template was included in the selective amplification.

cDNA products were visualized on 25 -cm-long sequencing gels $(0.25 \mathrm{~mm}$ thickness) prepared with $10 \%$ polyacrylamide gel solution (LongRanger), $7.0 \mathrm{M}$ urea and $1.2 \times$ TBE $(10 \times$ TBE stock: $89 \mathrm{mM}$ Tris, $89 \mathrm{mM}$ boric acid, and $2 \mathrm{mM}$ EDTA). Bands were separated by electrophoresis as follows: 1,500 V and $45 \mathrm{~V}$ at 
Table 1 Sequences of primers and adapter strands used for pre-amplification of digested cDNA fragments

\begin{tabular}{ll}
\hline Primer or adapter & Sequence \\
\hline Mse I adapter & 5'-GACGATGAGTCCTGAG-3' $^{\prime}$ \\
Taq I adapter & 5'-TACTCAGGACTCAT-3' $^{\prime}$-TACACGATGAGTCCTGAC-3' $^{\prime}$ \\
Mse I nonselective primer & $5^{\prime}$-CGGTCAGGACTCAT-3' \\
Taq I nonselective primer & $5^{\prime}$-GATGAGTCCTGAGTAA-3' \\
\hline
\end{tabular}

$50^{\circ} \mathrm{C}$, with a 25 -min pre-run and 3.5-h main run. Data images were collected using LI-COR's Saga AFLP Analysis software. Gel images were analyzed visually for the presence of differentially displayed fragments. Fragments were selected based on presence-absence criteria.

After identification of differentially expressed bands, samples were reloaded on $10 \%$ polyacrylamide gels and separated under the conditions described above. Gels were removed after $1 \mathrm{~h}$, and a grid was marked on the back glass plate to identify sample lanes along the $x$-axis and fragment size along the $y$-axis. The front glass plate was removed, and gels were laid face down on an Odyssey infrared imager (LiCor) and scanned. Target fragments were located within the grid, excised from the gels using a clean razor blade, and transferred to $1.5-\mathrm{ml}$ microcentrifuge tubes. Rescanning allowed verification that the intended band was excised. QIAquick Gel Extraction kit (Qiagen) was used to extract the target fragments from the gel slices. Extracted cDNA was re-amplified using the nonselective TaqI and MseI primers (Table 1 ) and checked on a $1 \%$ agarose gel to confirm the presence of a single band.

Differentially expressed bands and a few constitutive bands (50 ng) were isolated and inserted into the pCR 2.1-TOPO vector using the TOPO TA Cloning kit (Invitrogen) according to the manufacturer's instructions, then used to transform OneShot TOP10 Escherichia coli competent cells. Plasmids from selected bacterial colonies, grown overnight in Luria-Bertani broth containing $100 \mu \mathrm{g} / \mathrm{ml}$ ampicillin, were harvested using the FastPlasmid ${ }^{\mathrm{TM}}$ Mini kit (Eppendorf) and the insert confirmed by PCR. Purified plasmids containing one insert of the appropriate size were sent to the McGill University and Genome Québec Innovation Center for sequencing using M13F and M13R universal primers.

Sequences were identified through the NCBI genebank, TIGR M. truncatula EST, and plant transcript assembly databases using BLASTn to search sequences and were annotated based on their highest BLAST score with an $E$ value $<10^{-4}$ (Table 3; Altschul et al. 1990; Altschul et al. 1997; Childs et al. 2007). Putatively identified genes were grouped into categories according to their biological function.

\section{Quantitative Real Time-polymerase Chain Reaction}

Gene expression patterns were verified by quantitative real time PCR (qRT-PCR). In new biologically replicated experiments, plants were subject to wounding or caterpillar herbivory under conditions outlined above (greenhouse experiment). For each treatment, two independent biological replications were performed. Total RNA 
was extracted from approximately $100 \mathrm{mg}$ of ground leaf material using the RNeasy Plant Mini kit (Qiagen). A blank control was also taken through the following steps and used as the "no-template control" (NTC). The absence of genomic contamination was verified by amplifying the samples using primers (5'- CTCTCCT GCATTTCCACTTTC -3' and 5'- TTCTTGACCCTACCAAACATCA -3') which span an introgenic region. Then a cDNA copy was generated from $1 \mu \mathrm{g}$ total RNA using the QuantiTech Reverse Transcription kit (Qiagen).

Gene-specific primers were designed and transcript expression analyzed by qRTPCR using an Mx3000p thermal cycler (Stratagene). A standard curve was prepared for each gene using amplicons that had been sequenced for verification. Gene expression was performed in duplicate using the brilliant one-step quantitative RTPCR kit (Strategene) according to manufacturer's instructions. As well, non-template control (NTC) was included. The reaction mixtures contained $1 \times$ SYBR green I, $0.375 \mathrm{nM}$ ROX, $160 \mathrm{nM}$ each of gene-specific forward and reverse primers (Table 2), cDNA and the mastermix which contains dNTPs, $\mathrm{MgSO}_{4}$, and Taq polymerase. Thermocycler conditions were as follows: $95^{\circ} \mathrm{C}$ for $10 \mathrm{~min}$; 40 cycles of $60^{\circ} \mathrm{C}$ for $1 \mathrm{~min}$, then $72^{\circ} \mathrm{C}$ for $30 \mathrm{~s}$, followed by $95^{\circ} \mathrm{C}$ for $1 \mathrm{~min}$; one cycle of $55^{\circ} \mathrm{C}$ for $30 \mathrm{~s}$ and $95^{\circ} \mathrm{C}$ for $30 \mathrm{~s}$. To assess amplicon purity, a dissociation curve was performed. Two plate replicates were completed. From the standard curves, the gene copy numbers were estimated using Mx3000p MxPro v3.20 software.

A constitutively expressed elongation factor $1 \alpha$ gene $(M t E F)$ was identified by cDNA-AFLP. This gene has been determined to be an appropriate reference gene in other plant-stress systems (Nicot et al. 2005). To verify that $M t E F$ was stably expressed and not affected by treatments, transcript levels were analyzed by a oneway analysis of variance (ANOVA) using SPSS version 15 (SPSS Inc., Chicago, Il; Brunner et al. 2004). Relative gene expression was normalized to $M t E F$ gene expression. Results were averaged from two independent biological replications. A 1.8-fold difference in gene expression of enzymes (MtSTR, MtRCA, MtUnk) and a 1.6-fold difference in gene expression of the cellular regulators (MtRPK, MtTF) were determined to be appropriate criteria for difference in transcript expression.

\section{Bioinformatics}

Transcript protein sequences were computationally determined using SDSC Biology Workbench (www.workbench.sdsc.edu) using the program Sixframe and compared against orthologous sequences deposited at NCBI Genbank and TIGR databases

Table 2 Primers used for qRT-PCR expression analysis

\begin{tabular}{llll}
\hline Gene & Forward primer $\left(5^{\prime}-3^{\prime}\right)$ & Reverse primer $\left(5^{\prime}-3^{\prime}\right)$ & $\begin{array}{l}\text { Amplicon } \\
\text { size }(\mathrm{bp})\end{array}$ \\
\hline$M t S T R$ & ATTCTTCGGCTTTGGCTTCA & TCTCCTTCATCATCTAGCTTTACA & 152 \\
$M t R C A$ & CTCTCCTGCATTTCCACTTTC & TTCTTGACCCTACCAAACATCA & 159 \\
$M t U N K$ & TACAAGCAAAGGGACTTAGAGATG & TTACTGGCTTCTTTTGATGTG & 102 \\
$M t R P K$ & TCTTATCCAAAGACCGAACCA & GGTGAAAGGTAGTCTCGGGTA & 143 \\
$M t R F P$ & ACAAAATGGGCAAACTGGTC & ACAATTGAGGTCAAACCTTGTG & 120 \\
$M t E F$ & AGAAAGACTCACAGTTGAGCCA & TGGAGGAGAAGGGAGGAAAC & 145 \\
\hline
\end{tabular}


(Altschul et al. 1997). Putative genes were assigned functionality based on gene ontology (GO) annotations and percentages calculated based on the number of differentially expressed genes in each functional group divided by the total number of differentially expressed genes identified in this screen $\times 100$. Conserved protein domains were identified by Pfam, Interpro, and ExPASy Prosite (Altschul et al. 1997; Finn et al. 2006; Hulo et al. 2006; Marchler-Bauer et al. 2007; Quevillon et al. 2005; Schäffer et al. 2001). Putative transmembrane regions were identified by Phobius (Kall et al. 2004). Nuclear localization was determined using LocTREE (Nair and Rost 2005).

\section{Results}

cDNA-Amplified Fragment Length Polymorphism Analysis

M. truncatula plants were undamaged (cont), mechanically wounded (wnd), or subject to herbivory by caterpillars with intact (intact) or impaired (caut) salivary secretions. Cauterization of the caterpillar spinneret, which prevented labial salivary secretions, was used to enable the discrimination between genes regulated in response to salivary elicitors.

One hour after damage, early transcriptional responses to wounding or herbivory were identified by cDNA-AFLP using six selective primer pairs (Fig. 1)(Bachem et al. 1998; Bachem et al. 1996). Fragments were selected based on presence/ absence and/or differences in signal intensity between treatments. Twenty-five fragments were isolated and sequenced. Genes were identified based on BLASTn comparisons with Medicago truncatula database and plant transcript assemblies available at the Institute for Genomic Research (TIGR) and GenBank (National Center for Biotechnology Information (NCBI)). Occasionally, multiple gene fragments identified the same gene. In all, 16 genes that are putatively differentially expressed in response to wounding and/or caterpillar herbivory were identified (Table 3). These transcripts include those encoding defense- and stress-related proteins, proteins involved with cell signaling, and photosynthesis-related proteins (Fig. 2). The identification of several genes encoding proteins involved in cell signaling fits with the hypothesis that changes in plant gene expression are initiated rapidly, within an hour after herbivore damage.

\section{Gene Expression}

Expression patterns of five genes encoding rubisco activase $(M t R C A)$, strictosidine synthase $(M t S T R)$, a receptor-like protein kinase $(M t R P K)$, a zinc finger transcription factor $(M t R F P)$, and an unknown protein $(M t U N K)$ were verified by qRT-PCR (Fig. 3). When normalizing levels of gene expression, it is critical to have a reference gene whose expression is not influenced by the treatments. $M t E F$ was identified by cDNA-AFLP as being constitutively expressed. Across treatments, MtEF gene expression remained constant (one-way ANOVA, 1:5 dilution: $F_{(3,76)}=0.021, P=$ 0.996, 1:10 dilution: $F_{(3,36)}=0.080, P=0.970,1: 40$ dilution: $F_{(3,43)}=0.324, P=$ 0.808). Therefore, this is an appropriate reference gene for these herbivory experiments and used to normalize gene expression. 


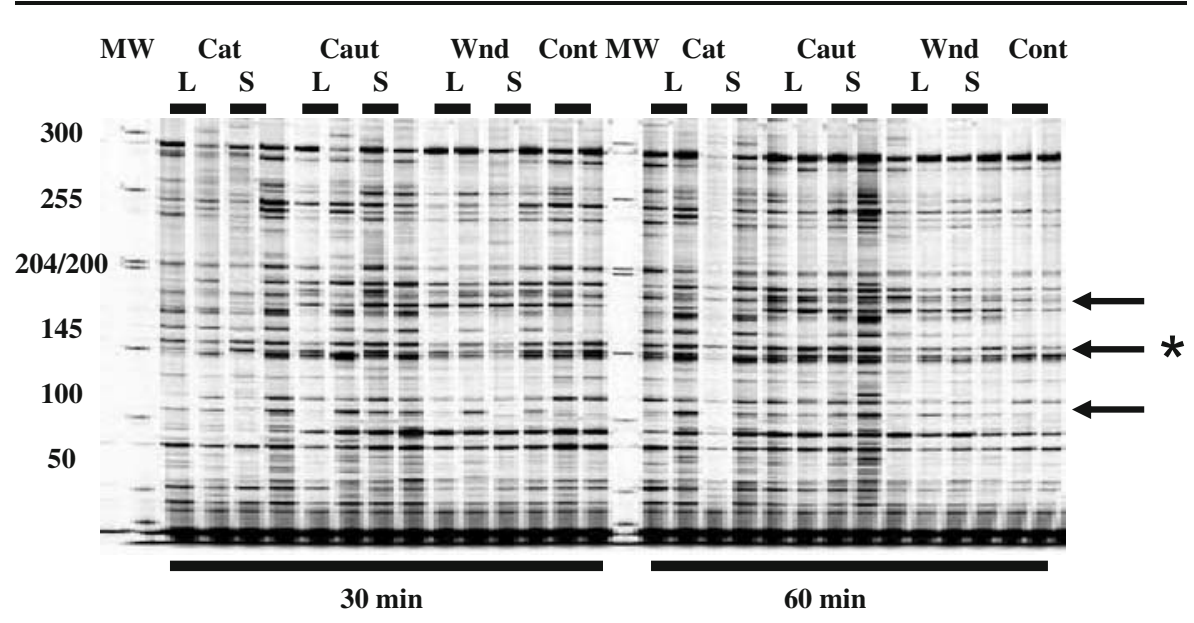

Fig. 1 Representative cDNA-AFLP gel of Medicago truncatula transcriptional responses to caterpillar herbivory. Duplicate lanes represent gene expression from 6-week-old Medicago truncatula plants undamaged controls (Cont) or which have been subject to mechanical wounding $(W n d)$ or herbivory by fourth instar S. exigua caterpillars with normal salivary function (Cat) or with disrupted salivary secretions (Caut). Leaf samples were taken 30 or $60 \mathrm{~min}$ after the initiation of the treatment and leaflets from the trifoliate divided into local ( $L$; damaged) or systemic ( $S$; undamaged). Lanes 1 and 16 represent the molecular weight marker $(M W)$. Duplicate lanes represent transcripts isolated from two independent biological replications. Differentially expressed genes were identified by presence/absence or large differences in band intensity between treatments. Arrows indicate a gene fragment that putatively shows caterpillar-specific expression. A star + arrow represents a gene fragment that represents a constitutively expressed transcript

For metabolic enzymes, a 1.8-fold difference in gene expression was used to verify changes in transcript patterns in response to treatments (Fig. 3). For putative cellular regulators, such as the receptor-like protein kinase $(M t R P K)$ and RING finger protein $(M t R F P)$, a 1.6-fold difference in gene expression was an acceptable difference in transcript levels. cDNA-AFLP identified MtRCA to be constitutively expressed with lower levels observed in the caterpillar treatments (intact, cauterized) (Table 3). qRT-PCR verified that MtRCA is constitutively expressed in control plants (Fig. 3a). In response to wounding or caterpillar herbivory (intact, cauterized) lower transcript levels were found; a 2-fold difference in gene expression was observed between leaves from control and caterpillar-infested plants. A similar pattern was observed for MtSTR where a 1.8-fold difference was observed between lower transcript levels in wound and caterpillar-treated plants compared to constitutive levels in control plants (Fig. 3b). This also was in agreement with cDNA-AFLP observations (Table 3). For transcript levels of the unknown protein (MtUNK), a twofold difference in gene expression was observed between control leaves and plants eaten by caterpillars which had impaired salivary secretions (cauterized; Fig. 3c). MtUNK expression levels in plants which were wounded or subject to herbivory by caterpillars with normal salivary secretions showing intermediary levels. Again, this closely follows what was observed by cDNA-AFLP (Table 3).

Two putative regulatory proteins were identified by the cDNA-AFLP screen (Table 3). The zinc RING finger protein (MtRFP) was constitutively expressed with lower levels found in plants which were eaten by caterpillars with salivary secretions 
Table 3 Medicago truncatula genes which are putatively differentially expressed in response to mechanical wounding and/or herbivory by fourth instar Spodoptera exigua caterpillars

\begin{tabular}{|c|c|c|c|}
\hline BLASTn match & Observed expression pattern ${ }^{\mathrm{a}}$ & $\begin{array}{l}\text { Transcript } \\
\text { assembly }\end{array}$ & $E$ value \\
\hline \multicolumn{4}{|c|}{ Photosynthesis and primary metabolism } \\
\hline Rubisco activase & $\begin{array}{c}\text { Constitutive, lower levels in } \\
\text { caterpillar treatments (cat) }\end{array}$ & TA18705_3880 & $2 \times 10^{-118}$ \\
\hline $\begin{array}{l}\text { Glyceraldehyde-3-P } \\
\text { dehydrogenase }\end{array}$ & $\begin{array}{l}\text { Weak in intact caterpillar group } \\
\text { only (intact) }\end{array}$ & TA19564_3880 & $7 \times 10^{-103}$ \\
\hline Plastocyanin & $\begin{array}{l}\text { Constitutive, higher levels in } \\
\text { caterpillar treatments (cat) }\end{array}$ & TA19727_3880 & $4.6 \times 10^{-46}$ \\
\hline $\begin{array}{l}\text { GDP-mannose } \\
\text { 3,5-epimerase }\end{array}$ & $\begin{array}{l}\text { Constitutive, higher levels in } \\
\text { caterpillar treatments (cat) }\end{array}$ & TA20683_3880 & $6.9 \times 10^{-41}$ \\
\hline \multicolumn{4}{|l|}{ Stress Proteins } \\
\hline $\begin{array}{l}\text { Transcription factor } \\
\mathrm{CBF} / \mathrm{NF}-\mathrm{Y} / \text { archeal histone }\end{array}$ & $\begin{array}{l}\text { Weakly constitutive, higher levels } \\
\text { in caterpillar treatment (cat) }\end{array}$ & TA23376_3880 & $2.8 \times 10^{-6}$ \\
\hline Receptor-like protein kinase & $\begin{array}{l}\text { Constitutive, higher levels in } \\
\text { caterpillar treatments (cat) }\end{array}$ & CA919558 & $5.8 \times 10^{-16}$ \\
\hline Zinc RING finger & $\begin{array}{l}\text { Constitutive, weaker in intact } \\
\text { caterpillar group (intact) }\end{array}$ & TA20008_3880 & $3.0 \times 10^{-17}$ \\
\hline \multicolumn{4}{|c|}{ Defense and secondary metabolism } \\
\hline $\begin{array}{l}\text { Naringenin-chalcone } \\
\text { synthase; type III } \\
\text { polyketide synthase }\end{array}$ & $\begin{array}{l}\text { Constitutive, lower levels wound } \\
\text { and intact caterpillar treatments } \\
\text { (wnd, intact) }\end{array}$ & TA20700_3880 & $1.1 \times 10^{-11}$ \\
\hline Strictosidine synthase & $\begin{array}{l}\text { Constitutive, lower levels wound } \\
\text { and caterpillar treatments (wnd, cat) }\end{array}$ & TA30174_3880 & $2.4 \times 10^{-22}$ \\
\hline \multicolumn{4}{|l|}{ Stress-related } \\
\hline CpABA1 & $\begin{array}{l}\text { Present in intact caterpillar treatment } \\
\text { (intact) }\end{array}$ & TA62789_3847 & $4.710^{-8}$ \\
\hline \multicolumn{4}{|l|}{ Transport } \\
\hline ABC transporter related; & Present in wounded leaf tissue (wnd) & TC98815 & $6.4 \times 10^{-10}$ \\
\hline \multicolumn{4}{|c|}{ Membrane structure and maintenance } \\
\hline $\begin{array}{l}60 \mathrm{kDa} \text { inner membrane } \\
\text { insertion protein }\end{array}$ & $\begin{array}{l}\text { Present in intact caterpillar treatment } \\
\text { (intact) }\end{array}$ & TA28784_3880 & $3.3 \times 10^{-26}$ \\
\hline \multicolumn{4}{|l|}{ Unknown biological process } \\
\hline Hypothetical protein (D9) & $\begin{array}{l}\text { Lower levels in intact caterpillars } \\
\text { (intact) }\end{array}$ & TA3900_57577 & $7.6 \times 10^{-34}$ \\
\hline $\begin{array}{l}\text { Protein of unknown } \\
\text { function (D13) }\end{array}$ & $\begin{array}{l}\text { Present in cauterized caterpillars } \\
(\text { caut })\end{array}$ & TA3413_3880 & $6.1 \times 10^{-13}$ \\
\hline Hypothetical protein (E5) & Induced in intact caterpillar (intact) & TA24282_3880 & $4.5 \times 10^{-34}$ \\
\hline $\begin{array}{l}\text { Hypothetical protein } \\
(M t U N K)\end{array}$ & $\begin{array}{l}\text { Constitutive, weaker in caterpillar } \\
\text { (cat) }\end{array}$ & TA32214_3880 & $4.1 \times 10^{-16}$ \\
\hline \multicolumn{4}{|l|}{ Constitutive genes } \\
\hline $\begin{array}{l}\text { NAD }(\mathrm{P}) \mathrm{H} \text {-plastoquinone } \\
\text { oxidoreductase }\end{array}$ & $\begin{array}{l}\text { Constitutive, not affected by } \\
\text { herbivory or wounding }\end{array}$ & TA20130_3880 & $1.3 \times 10^{-34}$ \\
\hline Elongation factor & $\begin{array}{l}\text { Constitutive, not affected by } \\
\text { herbivory or wounding }\end{array}$ & TA20137_3880 & $6.4 \times 10^{-57}$ \\
\hline
\end{tabular}

Nucleotide sequence were compared to the NCBI and TIGR plant transcript assembly databases by BLASTn or tBLASTx (Altschul et al. 1990; Childs et al. 2007).

wnd Wound, intact caterpillar with intact salivary secretions, caut caterpillars with impaired salivary secretions, cat caterpillars with intact or impaired salivary secretions 
Fig. 2 Division of Medicago truncatula genes which were putatively identified as differentially expressed in response to caterpillar herbivory or mechanical wounding by cDNA-AFLP according to gene ontology $(G O)$ annotation of biological function (Table 3)

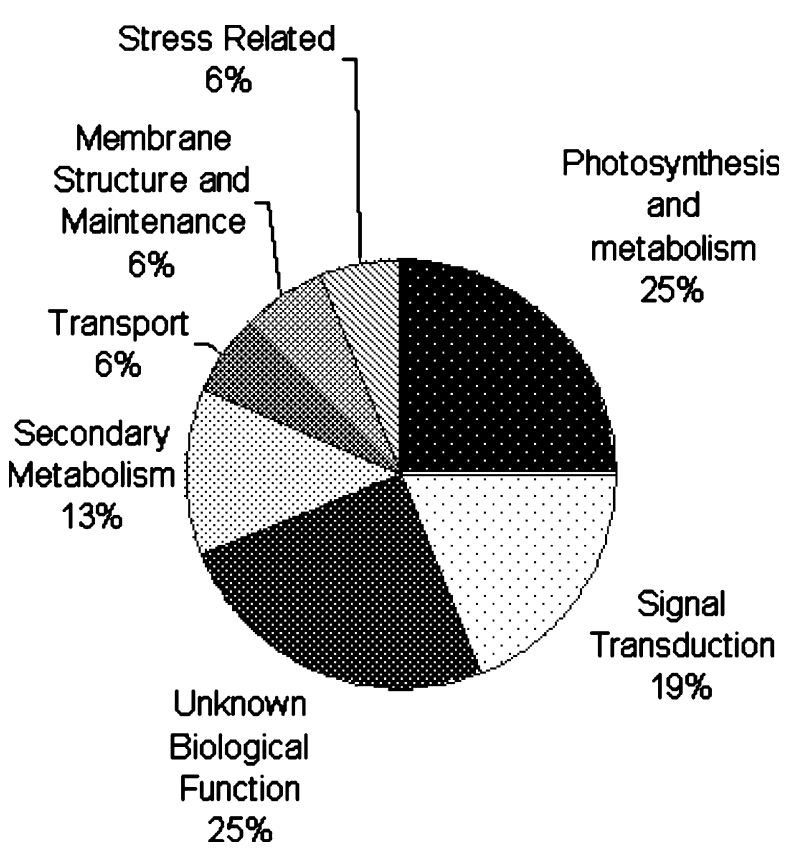

(intact) (Fig. 3d). Bioinformatic analysis predicts that this protein contains four ankyrin repeat domains and a zinc Cys3-His-Cys4 really interesting new gene (RING) finger.

In comparison to these genes which show decreased expression in response to treatments, the constitutive putative receptor-like protein kinase (MtRPK) showed higher expression levels in plants infested by caterpillars (both cauterized and intact). These expression patterns were verified by qRT-PCR (Fig. 3e). A 1.6-fold decrease in gene expression is observed in plants eaten by caterpillars with impaired salivary secretions (cauterized) compared to control plants. For all the genes described, wounded plants show similar expression patterns to plants infested by caterpillar herbivory except for $M t R P K$ which shows caterpillar-specific transcript expression.

\section{Discussion}

In response to wounding and/or caterpillar herbivory, 16 genes were identified as putatively expressed and assigned into broad functional groups based on gene ontology (GO) annotations (Table 3, Fig. 2). Several transcripts showing homology to geneencoding proteins involved in photosynthesis and primary metabolism were identified. According to the cDNA-AFLP data, a transcript encoding glyceraldehyde-3-phosphate dehydrogenase $(M t G A P)$ was expressed in plants treated with caterpillars with normal salivary function but not when fed upon by caterpillars with impaired salivary secretions. Therefore, caterpillars which secrete GOX and other salivary elicitors onto the tissue as they are feeding induce $M t G A P$ gene expression. Hancock et al. (2005) identified this protein as a possible $\mathrm{H}_{2} \mathrm{O}_{2}$-sensing protein and suggest that GADPH 


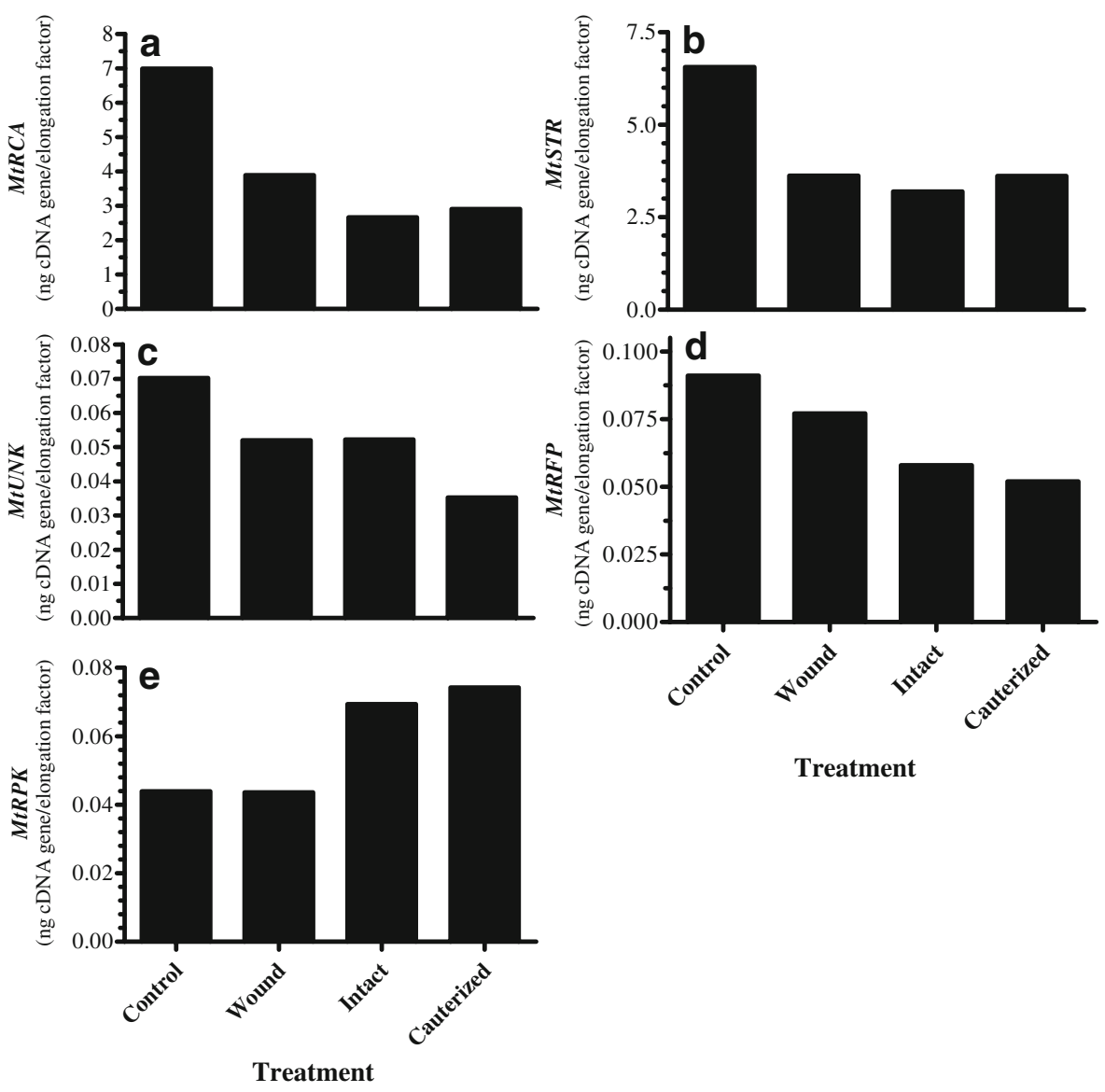

Fig. 3 Wound- and caterpillar-specific Medicago truncatula gene expression. M. truncatula plants were undamaged (control) or subject to mechanical wounding (wound) or herbivory by caterpillars with intact (intact) or impaired (cauterized) salivary secretions. Transcript expression patterns of five genes a MtRCA, b $M t S T R$, c $M t U n k$, d MtRFP, and e MtRPK, which encode rubisco activase, strictosidine synthase, an unknown protein, a RING finger protein and a receptor-like protein kinase, respectively, were analyzed by qRT-PCR using gene-specific primers shown in Table 2. Gene copy number was calculated from the standard curve and bars represent transcript levels normalized using elongation factor $(M t E F)$ as a reference gene. The experiment was repeated with similar results

may have additional roles in the plant, such as in cellular signaling (Kim et al. 2003). This gene is up-regulated in the Solanaceous plants N. attenuata and Solanum nigrum in response to $M$. sexta herbivory and overrepresented in a wound-induced Poplar (Populus trichocarpa $\times$ P. deltoides) expressed sequence tag (EST) library (Christopher et al. 2004; Schmidt et al. 2005).

Higher transcript levels of GDP-mannose 3,5-epimerase in response to caterpillar herbivory were found by cDNA-AFLP. In plants, this enzyme catalyzes a key step in the biosynthesis of ascorbate. This vitamin is not only an important enzymatic cofactor but also associated with plant stress responses, acting both as a strong antioxidant and a mediator in plant stress responses (Pastori et al. 2003; Pavet et al. 2005; Smith et al. 2007). Expression levels of GDP-mannose 3,5-epimerase are 
induced in tobacco BY-2 suspension cultures by treatment with the wound-related phytohormone methyl jasmonate (MeJA), which together with this cDNA-AFLP data suggests that ascorbate may also play a role in plant defense against caterpillar herbivory (Wolucka et al. 2005).

In response to caterpillar herbivory, plants often redirect metabolic flux from primary pathways into secondary metabolism; therefore, a reduction in photosynthesis and lower gene expression of photosynthetic-related genes may be observed (Hermsmeier et al. 2001; Schmidt et al. 2005; Zangerl et al. 2002). Genes encoding photosynthetic-associated genes, such as ribulose-1,5-bisphosphate carboxylase/ oxygenase activase (rubisco activase; MtRCA) and plastocyanin (MtPC), were constitutively expressed. In response to caterpillar herbivory, cDNA-AFLP analysis found that caterpillar-infested M. truncatula plants had higher expression levels of $M t P C$. In comparison, transcript levels of $M t R C A$ were lower in caterpillar-treated plants. This was verified by qRT-PCR where gene expression in control plants is approximately twofold higher than wound- or caterpillar-treated plants. Similar patterns of gene expression have been observed in Nicotiana longiflora-Manduca sexta interactions (Izaguirre et al. 2006). In contrast, NaRCA transcription is induced after $24 \mathrm{~h}$ of infestation of $N$. attenuata with the piercing/sucking mirid bug Tupiocoris notatus (Voelckel and Baldwin 2003). Rubisco activase, a regulatory enzyme of photosynthesis, is controlled at many levels, including transcriptionally and in response to biotic and abiotic stresses, including drought (DeRidder and Salvucci 2007; Portis 2003; Zhang et al. 2002). Under favourable environmental conditions, rubisco activase maintains the functionality of the photosynthetic enzyme ribulose-1,5-bisphosphate carboxylase/oxygenase (Rubisco) by actively removing inhibitory carbohydrates from the Rubisco substrate binding site. However, rubisco activase is extremely sensitive to heat stress or drought which results in decreased activity and, hence, lower photosynthesis levels. As a caterpillar feeds on the plant leaf, the exposed tissue is subject to water losses (Tang et al. 2006). Therefore, decreases in MtRCA transcript expression in response to caterpillar herbivory may be related to water evaporation from herbivore-wounded leaves.

Expression of another gene, MtABA1, identified by cDNA-AFLP to be regulated in a caterpillar-specific manner, is also associated with drought and salinity stress (Xiong et al. 2002). This gene encodes the enzyme zeaxanthin epoxidase which catalyzes two early steps in the biosynthesis of abscisic acid (ABA), which regulates stomatal closure (Borel et al. 2001; Israelsson et al. 2006). This, again, suggests that water losses from the leaves during herbivory, even if minor, may affect downstream transcriptional responses. ABA has been implicated in the regulation of Arabidopsis thaliana responses to herbivory by caterpillars of the cabbage white moth, Pieris rapae, and Egyptian cotton worm, S. littoralis (Bodenhausen and Reymond 2007). In comparison, $\mathrm{ABA}$ levels measured in corn are not affected by herbivory with caterpillars of the corn earworm, Heliocoverpa zea (Schmeltz et al. 2003).

Genes involved in plant defense were also identified by cDNA-AFLP. Transcript levels of genes encoding chalcone synthase $(\mathrm{MtCHS})$ and strictosidine synthase (MtSTR) were lower in plants subject to wounding or caterpillar herbivory. Chalcone synthase catalyzes the first committed step in flavonoid biosynthesis, and CHS expression levels are often induced in response to mechanical wounding, insect herbivory, or treatment with jasmonic acid or related compounds (Richard et al. iㅡㄹ Springer 
2000; Ryder et al. 1987; Sakuta 2000). Lower transcript levels observed by cDNAAFLP were not expected. However, chalcone synthase $(\mathrm{MtCHS})$ is a large gene family with at least ten members. Global expression analysis of M. truncatula tissue cultures which were treated with MeJA shows four members of this gene family that have lower transcriptional levels $24 \mathrm{~h}$ after treatment (Ryder et al. 1987).

Strictosidine synthase catalyzes the condensation of tryptamine and secologanin to form strictosidine, the backbone of terpenoid indole alkaloids (TIAs). Little is known about the role of indole alkaloids in M. truncatula but increasing evidence suggests that alkaloids may play a defensive role in legumes (Phan et al. 2007; Tellström et al. 2007). Strictosidine, itself, does not have antifeedent activity, but may be an intermediate to more toxic alkaloids (Luijendijk et al. 1996). MtSTR gene expression was transcriptionally regulated in response to herbivory with lower levels detected in plants damaged by wounding or infested with caterpillars with normal salivary secretions. In comparison, STR gene expression in induced in response to mechanical wounding in Arabidopsis and wounding and herbivory by caterpillars of the diamondback moth, Plutella xylostella in the related Brassicacea canola, Brassica napus (Cheong et al. 2002; Sarosh and Meijer 2007); however, gene expression was only noted $6 \mathrm{~h}$ after treatment. In Catharanthus roseus, strictosidine synthase transcript expression is regulated in a jasmonate-dependent manner by ORCA transcription factors (Memelink and Gantet 2007; van der Fits and Memelink 2000). Again, these differences may represent species-specific approaches to plant defenses. C. roseus is recognized for using TIAs as part of its defense against insect herbivores (van Dam et al. 1993). In comparison, isoflavonoids and triterpene saponins are believed to play a role in protection of $M$. truncatula aerial tissues (Achnine et al. 2005; Agrell et al. 2003; Naoumkina et al. 2007; Suzuki et al. 2005; Urbanczyk-Wochniak and Sumner 2007).

cDNA-AFLP identified a wound-induced ATP-binding cassette (ABC)-related transporter. This protein superfamily hydrolyze ATP to drive the translocation of compounds, such as alkaloids, terpenoids and phenolics, across membranes and, therefore, may be an important part of the plant defense response against insect herbivory (Rea 2007; Yazaki 2006). The rapid decrease of transcript levels of an ABC-transporter observed after M. sexta caterpillar feeding on Nicotiana attenuata is followed by steadily increase to peak levels at $12 \mathrm{~h}$ (Hui et al. 2003). Induced transcript expression of ABC transporters was also observed in M. truncatula suspension cultures treated with the wound-related hormone methyl jasmonate (Naoumkina et al. 2007).

Three genes which encode proteins of unknown function were identified by this experiment. The expression pattern of MtUnk (homology to AC167959.39) was verified by qRT-PCR and shown to have constitutive expression with lower transcript levels in response to caterpillar herbivory.

In the differential screen, three putative genes involved in cellular signaling were identified. A transcript fragment with high homology to a NF-Y transcription factor appears to be induced in plants exposed to caterpillar herbivore. NF-Y belongs to a family of CCAAT-box binding transcription factors that are often involved in plant development and stress responses (Mantovani 1999; Nelson et al. 2007). In wheat, Triticum aestivum, $11 \mathrm{TaNF}$-Y-related genes were transcriptionally regulated in response to drought stress (Stephenson et al. 2007); again, suggesting a link between caterpillar herbivory and plant responses to water stress in locally wounded leaves. 
Zinc RING finger proteins are involved in the cellular regulation of many plant physiological processes (Takatsuji 1998). These proteins are predicted to have four ankyrin repeat domains and a Cys3-His-Cys4 zinc finger domain. Ankyrin repeats are involved in protein-protein associations (Mosavi et al. 2004). The predicted RING finger conformation forms a cross-brace which is coordinated by two zinc ions; this forms a highly stable scaffold for molecular interactions, and these proteins are involved in protein-protein, protein-RNA, and protein-DNA interactions (Brown 2005; Gamsjaeger et al. 2007; Kosarev et al. 2002; Tatatsuji 1998). Recently, zinc RING finger proteins have been recognized as E3 ubiquitin ligases that target proteins for ubiquitination and proteosome-mediated degradation (Aravind and Koonin 2000; Gamsjaeger et al. 2007). MtRFP is constitutively expressed in M. trunctula leaves, and levels decrease upon wounding or caterpillar herbivory. A microarray study also identified zinc finger RING proteins that are differentially expressed in response to wounding (Cheong et al. 2002). Bioinformatic analysis has predicted that MtRFP is nuclear; therefore, this protein may be involved in transcriptional regulation either by interacting directly with the genome or functioning as a scaffold in protein-protein interactions with a transcription factor. Many plant cellular regulators, including jasmonate ZIM-domain (JAZ) proteins which regulate jasmonate-dependent gene expression, function as negative regulators (Broun 2004; Singh et al. 2002; Thines et al. 2007); therefore, the lower $M t R F P$ levels observed in response to wounding and herbivory may result in the induction of plant defense gene expression. Alternatively, MtRFP may function as an E3 ubiquitin ligase. Many members encoded by this gene family, such as tomato LeATL6 and Arabidopsis COI1, are involved in the regulation of jasmonateassociated plant responses to stresses (Hondo et al. 2007; Smalle and Vierstra 2004; $\mathrm{Xu}$ et al. 2002).

A constitutive receptor-like protein kinase $(M t R P K)$ was identified as induced in response to caterpillar herbivory by cDNA-AFLP. This was verified by qRT-PCR; a 1.6-fold increase in transcript expression is observed in plants fed upon by caterpillars with intact or impaired salivary secretions. This response is caterpillar-specific, as gene levels in wound and control plants are similar. Receptor protein kinases are key players in plant signal transduction pathways (Haffani et al. 2004; Shiu and Bleecker 2001). The receptor protein kinase identified in this screen has a predicted transmembrane domain, an ATP-binding site, and serine/threonine kinase activity.

The robust differential display technique cDNA-AFLP identified promising candidate genes which were expressed in a wound- and/or caterpillar-specific manner. Expression patterns of five of these genes were verified by qRT-PCR. This study has shown that $M$. truncatula initiates transcriptional changes within an hour of suffering caterpillar herbivory. Though most transcripts examined were constitutively expressed and lower levels observed in plants which were wounded or subject to caterpillar herbivory, MtRPK levels increased in a caterpillar-specific manner. None of the five transcripts, however, showed differential patterns which reflected the presence or absence of caterpillar salivary secretions. Together, these results provided evidence that M. truncatula is able to respond quickly and specifically to herbivory and wounding.

Acknowledgments We thank Yao Hua Law and Bejay Mills for caterpillar maintenance. We thank Dr. Korban and an anonymous review for insightful comments on an earlier version of this manuscript. This 
research was supported through grants from the National Sciences and Engineering Research Council, Infrastructure Operating Fund and Fonds Québécois de la Recherche sur la Nature et les Technologies (FQRNT). Instruments used in this research were purchased through grants from the Canadian Foundation for Innovation.

\section{References}

Achnine L, Huhman DV, Farag MA, Sumner LW, Blount JW, Dixon RA. Genomics-based selection and functional characterization of tripterpene glycosyltransferases from the model legume Medicago truncatula. Plant J 2005;41:875-87.

Agrell J, Oleszek W, Stochmal A, Olsen M, Anderson P. Herbivore-induced responses in alfalfa (Medicago sativa). J Chem Ecol 2003;29:303-20.

Alborn HT, Turlings TCJ, Jones TH, Stenhagen G, Loughrin JH, Tumlinson J III. An elicitor of plant volatiles from beet armyworm oral secretions. Science 1997;276:945-9.

Altschul SF, Gish W, Miller W, Myers EW, Lipman DJ. Basic local alignment search tool. J Mol Biol 1990;215:403-10.

Altschul SF, Madden TL, Schäffer AA, Zhang J, Zhang Z, Miller W, et al. Gapped BLAST and PSIBLAST: a new generation of protein database search programs. Nucleic Acids Res. 1997;25:3389402.

Aravind L, Koonin EV. The U box is a modified RING finger-a common domain in ubiquitination. Curr Biol. 2000;10:R132-4.

Azidah AA, Sofian-Azirun M. Life history of Spodoptera exigua (Lepidoptera: Noctuidae) on various host plants. Bull Entomol Res. 2006;96:613-8.

Babic B, Poisson A, Darwish S, Lacasse J, Merkx-Jacques M, Despland E, et al. Influence of dietary nutritional composition on caterpillar salivary enzyme activity. J Insect Physiol. 2008;54:286-96.

Bachem CWB, Van der Hoeven RS, deBruijin SM, Vreugdenhil D, Zabeau M, Visser RGF. Visualization of differential gene expression using a novel method of RNA fingerprinting based on AFLP: analysis of gene expression during tuber development. Plant J. 1996;9:745-53.

Bachem CWB, Oomen RJFJ, Visser RGF. Transcript imaging with cDNA-AFLP: a step-by-step protocol. Plant Mol Biol Report. 1998;16:157-73.

Bede JC, Musser RO, Felton GW, Korth KL. Caterpillar herbivory and salivary enzymes decrease transcript levels of Medicago truncatula genes encoding early enzymes in terpenoid biosynthesis. Plant Mol Biol. 2006;60:519-31.

Bergmeyer HU. Reagents for enzymatic analysis. Weinheim: Verlag Chemie; 1974. p. 494-5.

Bodenhausen N, Reymond P. Signaling pathways controlling induced resistance to insect herbivores in Arabidopsis. Mol Plant-Microbe Interact. 2007;20:1406-20.

Borel C, Audran C, Frey A, Marion-Poll A, Tardieu F, Simonneau T. N. plumbaginifolia zeaxanthin epoxidase transgenic lines have unaltered baseline ABA accumulations in roots and xylem sap, but contrasting sensitivities of ABA accumulation to water deficit. J Exp Bot. 2001;52:427-34.

Broun P. Transcription factors as tools for metabolic engineering in plants. Curr Opin Plant Biol. 2004;7:202-9.

Brown RS. Zinc finger proteins: getting a grip on RNA. Curr Opin Struck Biol. 2005;15:94-8.

Brunner AM, Yakovlev IA, Strauss SH. Validating internal controls for quantitative plant gene expression studies. BMC Plant Biol 2004;4:14.

Cannon SB, Crow JA, Heuer ML, Wang X, Cannon EKS, Dwan C, et al. Databases and information integration for the Medicago truncatula genome and transcriptome. Plant Physiol. 2005;138:38-46.

Chamnongpol S, Willekens H, Moeder W, Langebartels C, Sandermann H Jr, Van Montagu M, et al. Defense activation and enhanced pathogen tolerance induced by $\mathrm{H}_{2} \mathrm{O}_{2}$ in transgenic tobacco. Proc Natl Acad Sci. 1998;95:5818-23.

Cheong YH, Chang H-S, Gupta R, Wang X, Zhu T, Luan S. Transcriptional profiling reveals novel interactions between wounding, pathogen, abiotic stress, and hormonal responses in Arabidopsis. Plant Physiol. 2002;129:661-77.

Childs KL, Hamilton JP, Zhu W, Ly E, Cheung F, Wu H, et al. The TIGR plant transcript assembiles database. Nucleic Acids Res. 2007;35:D846-51.

Christopher ME, Miranda M, Major IT, Constabel CP. Gene expression profiling of systemically woundinduced defenses in hybrid poplar. Planta 2004;219:936-47. 
DeRidder BP, Salvucci ME. Modulation of Rubisco activase gene expression during heat stress in cotton (Gossypium hirsutum L.) involves post-transcriptional mechanisms. Plant Sci. 2007;172:246-54.

Eichenseer H, Mathews MC, Jian LB, Murphy JB, Felton GW. Salivary glucose oxidase: multifunctional roles for Helicoverpa zea. Arch Insect Biochem Physiol. 1999;42:99-109.

Engelberth J, Alborn HT, Schmeltz EA, Tumlinson J III. Airborne signals prime plants against insect herbivore attack. Proc Natl Acad Sci. 2004;101:1781-7.

Ferry N, Edwards MG, Gatehouse JA, Gatehouse AMR. Plant-insect interactions: molecular approaches to insect resistance. Curr Opin Plant Biol. 2004;15:155-61.

Finn RD, Mistry J, Schulster-Böckler B, Griffiths-Jones S, Hollich V, Lassmann T, et al. Pfam: clans, webtools and services. Nucleic Acids Res. 2006;34:D-247-51.

Gamsjaeger R, Liew CK, Loughlin FE, Crossley M, Mackay JP. Sticky fingers: zinc-fingers as proteinrecognition motifs. Trends Biochem Sci. 2007;32:63-70.

Gatehouse JA. Plant resistance towards insect herbivores. A dynamic interaction. New Phytol. 2002;156:145-69.

Greenberg SM, Sappington TW, Legaspi BC, Liu T-X, Sétamou M. Feeding and life history of Spodoptera exigua (Lepidoptera: Noctuidae) on different host plants. Ann Entomol Soc Am. 2001;94:566-75.

Haffani YZ, Silva NF, Goring DR. Receptor kinase signalling in plants. Can J Bot. 2004;82:1-15.

Hall DE, MacGregor KB, Nijsse J, Bown AW. Footsteps from insect larvae damage leaf surfaces and initiate rapid responses. Eur J Plant Pathol. 2004;110:441-7.

Hancock JT, Henson D, Nyirenda M, Desikan R, Harrison J, Lewis L, et al. Proteomic identification of glyceraldehyde 3-phosphate dehydrogenase as an inhibitory target of hydrogen peroxide in Arabidopsis. Plant Physiol Biochem. 2005;43:823-35.

Hermsmeier D, Schittko U, Baldwin IT. Molecular interactions between the specialist herbivore Manduca sexta (Lepidoptera, Sphingidae) and its natural host Nicotiana attenuata. I. Large-scale changes in the accumulation of growth- and defense-related plant mRNAs. Plant Physiol. 2001;125:683-700.

Hondo D, Hase S, Kanayama Y, NYoshikawa N, Takenaka S, Takahashi H. The LeATL6-associated ubiquitin/proteasome system may contribute to fungal elicitor-activated defense response via the jasmonic acid-dependent signaling pathway in tomato. Mol Plant-Microbe Interact 2007;20:72-81.

Hui D, Iqbal J, Lehmann K, Gase K, Saluz HP, Baldwin IT. Molecular interactions between the specialist herbivore Manduca sexta (Lepidoptera, Sphingidae) and its natural host Nicotiana attenuata: V. Microarray analysis and further characterization of large-scale changes in herbivore-induced mRNAs. Plant Physiol. 2003;131:1877-93.

Hulo N, Bairoch A, Bulliard V, Cerutti L, De Castro E, Langendijk-Genevaux PS, et al. The PROSITE database. Nucleic Acids Res 2006;34:D227-30.

Israelsson M, Siegel RS, Young J, Hashimoto M, Iba K, Schroeder JI. Guard cell ABA and CO2 signaling network updates and $\mathrm{Ca}^{2+}$ sensor priming hypothesis. Curr Opin Plant Biol. 2006;9:654-63.

Izaguirre MM, Mazza CA, Biondini M, Baldwin IT, Ballaré CL. Remote sensing of future competitors: impacts on plant defenses. Proc Natl Acad Sci. 2006;103:7170-4.

Kall L, Krogh A, Sonnhammer ELL. A combined transmembrane topology and signal peptide prediction method. J Mol Biol. 2004;338:1027-36.

Kessler A, Baldwin IT. Defensive function of herbivore-induced plant volatile emissions in nature. Science 2001;291:2141-4.

Kessler A, Baldwin IT. Plant responses to insect herbivory: The emerging molecular analysis. Annu Rev Plant Biol. 2002;53:299-328.

Kessler A, Halitschke R. Specificity and complexity: the impact of herbivore-induced plant responses on arthropod community structure. Curr Opin Plant Biol. 2007;10:409-14.

Kim JH, Lee S, Park JB, Lee SD, Kim JH, Ha SH, et al. Hydrogen peroxide induces association between glyceraldehyde 3-phosphate dehydrogenase and phospholipase D2 to facilitate phospholipase D2 activation in PC12 cells. J Neurochem. 2003;85:1228-36.

Kosarev P, Mayer KFX, Hardtke CS. Evaluation and classification of RING-finger domains encoded by the Arabidopsis genome. Genome Biol 2002;3:RESEARCH0016. (http://genomebiology.com/2002/3/ 4/research/0016.1).

Léon J, Rojo E, Sánchez-Serrano JJ. Wound signaling in plants. J Exp Bot. 2001;51:1-9.

Liu F, Cui L, Cox-Foster D, Felton GW. Characterization of a salivary lysozyme in larval Helicoverpa zea. J Chem Ecol. 2004;30:2439-57.

Luijendijk TJC, Van der Meijden E, Verpoorte R. Involvement of strictosidine as a defensive chemical in Catharanthus roseus. J Chem Ecol. 1996;22:1355-65. 
Maffei ME, Mithofer A, Boland W. Before gene expression: early events in plant-insect interactions. Trends in Plant Sci. 2007;12:1360-85.

Mantovani R. The molecular biology of the CCAAT-binding factor NF-Y. Gene 1999;239:15-27.

Marchler-Bauer A, Anderson JB, Derbyshire MK, DeWeese-Scott C, Gonzales NR, Gwandz M, et al. CCD: a conserved domain database for interactive domain family analysis. Nucleic Acids Res. 2007;35:D237-40.

Mathews MC, Summers CB, Felton GW. Ascorbate peroxidase: a novel antioxidant enzyme in insects. Arch Insect Biochem Physiol. 1997;34:57-68.

McGrath KC, Dombrecht B, Manners JM, Schenk PM, Edgar CI, Maclean DJ, et al. Repressor- and activator-type ethylene response factors functioning in jasmonate signaling and disease resistance identified via a genome-wide screen of Arabidopsis transcription factor gene expression. Plant Physiol. 2005;139:949-59.

Memelink J, Gantet P. Transcription factors involved in terpenoid indole alkaloid biosynthesis in Catharanthus roseus. Phytochem Rev. 2007;6:353-62.

Merkx-Jacques M, Bede JC. Influence of diet on the larval beet armyworm, Spodoptera exigua, glucose oxidase activity. J Insect Sci. 2005;5:48.

Mosavi LK, Cammett TJ, Desrosiers DC, Peng Z-Y. The ankyrin repeat as molecular architecture for protein recognition. Protein Sci. 2004;13:1436-48.

Mou Z, Fan W, Dong X. Inducers of plant systemic acquired resistance regulate NPR1 function through redox changes. Cell 2003;113:935-44.

Musser RO, Hum-Musser SM, Eichenseer H, Peiffer M, Ervin G, Murphy JB, et al. Caterpillar saliva beats plant defences: a new weapon emerges in the evolutionary arms race between plants and herbivores. Nature 2002;416:599-600.

Musser RO, Cipollini DF, Hum-Musser SM, Williams SA, Brown JK, Felton GW. Evidence that the caterpillar salivary enzyme glucose oxidase provides herbivore offense in Solanaceous plants. Arch Insect Biochem Physiol. 2005a;58:128-37.

Musser RO, Kwon HS, Williams SA, White CJ, Romano MA, Holt SM, et al. Evidence that caterpillar labial saliva suppresses infectivity of potential bacterial pathogens. Arch Insect Biochem Physiol. 2005b;58:138-44.

Nair R, Rost B. Mimicking cellular sorting improves prediction of subcellular localization. J Mol Biol. 2005;348:85-100.

Naoumkina M, Farag MA, Sumner LW, Tang Y, Liu C-J, Dixon RA. Different mechanisms for phytoalexin induction by pathogen and wound signals in Medicago truncatula. Proc Natl Acad Sci 2007;104:17909-15.

Nelson DE, Repetti PP, Adams TR, Creelman RA, Wu J, Warner DC, et al. Plant nuclear factor Y (NF-Y) B subunits confer drought tolerance and lead to improved corn yields on water-limited acres. Proc Natl Acad Sci. 2007;104:16450-5.

Nicot N, Hausman J-F, Hoffman L, Evers D. Housekeeping gene selection for real-time RT-PCR normalization in potato during biotic and abiotic stress. J Exp Bot. 2005;56:2907-14.

Pastori GM, Kiddle G, Antoniw J, Bernard S, Veljovic-Jovanovic S, Verrier PJ, et al. Leaf vitamin C contents modulate plant defense transcripts and regulate genes that control development through hormone signaling. The Plant Cell 2003;15:939-51.

Pavet V, Olmos E, Kiddle G, Mowla S, Kumar S, Antoniw J, et al. Ascorbic acid deficiency activates cell death and disease resistance responses in Arabidopsis. Plant Physiol. 2005;139:1291-303.

Peiffer M, Felton GW. The host plant as a factor in the synthesis and secretion of salivary glucose oxidase in larval Helicoverpa zea. Arch Insect Biochem Physiol. 2005;58:106-13.

Phan HTT, Ellwood SR, Adhikari K, Nelson MN, Oliver RP. The first genetic and comparative map of white lupin (Lupinus albus L.): Identification of QTLs for anthracnose resistance and flowering time, and a locus for alkaloid content. DNA Res. 2007;14:59-70.

Pieterse CM, van Loon L. NPR1: the spider in the web of induced resistance signaling pathways. Curr Opin Plant Biol. 2004;7:456-64.

Portis AR Jr. Rubisco activase-Rubisco's catalytic chaperone. Photosynth Res. 2003;75:11-27.

Quevillon E, Silventoinen V, Pallai S, Harte N, Mulder N, Apweiler R, et al. InterProScan: protein domains identifier. Nucleic Acids Res. 2005;33:W116-20.

Rea PA. Plant ATP-binding cassette transporters. Annu Rev Plant Biol. 2007;58:347-75.

Richard S, Lapointe G, Rutledge RG, Séguin A. Induction of chalcone synthase expression in white spruce by wounding and jasmonate. Plant Cell Physiol. 2000;41:982-7.

Ryan CA. Oligosaccharide signals: From plant defense to parasite offense. Proc Natl Acad Sci. 1994;91:1-2. 
Ryder TB, Hendrick SA, Bell JN, Liang X, Clouse SD, Lamb CJ. Organization and differential activation of a gene family encoding the plant defense enzyme chalcone synthase in Phaseolus vulgaris. Mol Gen Genet. 1987;210:219-33.

Sakuta M. Transcriptional control of chalcone synthase by environmental stimuli. J Plant Res. 2000;113:327-33.

Sarosh BR, Meijer J. Transcriptional profiling by cDNA-AFLP reveals novel insights during methyl jasmonate, wounding and insect attack in Brassica napus. Plant Mol Biol. 2007;64:425-38.

Schäffer AA, Aravind L, Madden TL, Shavirin S, Spouge JL, Wolf YI, et al. Improving the accuracy of PSI-BLAST protein database searches with composition-based statistics and other refinements. Nucleic Acids Res. 2001;29:2994-3005.

Schilmiller AL, Howe GA. Systemic signaling in the wound response. Curr Opin Plant Biol. 2005;8:36977.

Schmeltz EA, Engelberth J, Alborn HT, O'Donnell P, Sammons M, Toshima H, et al. Simultaneous analysis of phytohormones, phytotoxins, and volatile organic compounds in plants. Proc Natl Acad Sci. 2003;100:10552-7.

Schmidt DD, Voelckel C, Hartl M, Schmidt S, Baldwin IT. Specificity in ecological interactions. Attack from the same lepidopteran herbivore results in species-specific transcriptional responses in two solanaceous host plants. Plant Physiol. 2005;138:1763-73.

Shiu S-H, Bleecker AB. Plant receptor-like kinase gene family: diversity, function, and signaling. Science STKE. 2001;2001:RE22. (www.stke.org/cgi/content/full/OC_sigtrans;2001/113/re22).

Singh KB, Foley RC, Oñate-Sánchez L. Transcription factors in plant defense and stress responses. Curr Opin Plant Biol. 2002;5:430-6.

Smalle J, Vierstra RD. The ubiquitin $26 \mathrm{~S}$ proteasome proteolytic pathway. Annu Rev Plant Biol. 2004;55:555-90.

Smith AG, Croft MT, Moulin M, Webb ME. Plants need their vitamins too. Curr Opin Plant Biol. 2007;10:266-75.

Stephenson TJ, McIntyre CL, Collet C, Xue G-P. Genome-wide identification and expression analysis of the NF-Y family of transcription factors in Triticum aestivum. Plant Mol Biol. 2007;65:77-92.

Suzuki H, Reddy MSS, Naoumkina M, Aziz N, May GD, Huhman DV, et al. Methyl jasmonate and yeast elicitor induce differential transcriptional and metabolic re-programming in cell suspension cultures of the model legume Medicago truncatula. Planta 2005;220:696-707.

Takatsuji H. Zinc-finger transcription factors in plants. Cell Mol Life Sci. 1998;54:582-96.

Tang JY, Zielinski RE, Zangerl AR, Crofts AR, Berenbaum MR, DeLucia EH. The differential effects of herbivory by first and fourth instars of Trichoplusia ni (Lepidoptera: Noctuidae) on photosynthesis in Arabidopsis thaliana. J Exp Bot. 2006;57:527-36.

Tatatsuji H. Zinc-finger transcription factors in plants. Cell Mol Life Sci. 1998;54:582-96.

Tellström V, Usadel B, Thimm O, Stitt M, Küster H, Niehaus K. The lipopolysaccaride of Sinorhizobium meliloti suppresses defense-associated gene expression in cell cultures of the host plant Medicago truncatula. Plant Physiol. 2007;143:825-37.

Thines B, Katsir L, Melotto M, Niu Y, Mandaokar A, Liu G, et al. JAZ repressor proteins are targets of the SCFCOI1 complex during jasmonate signaling. Nature 2007;448:661-5.

Town CD. Annotating the genome of Medicago truncatula. Curr Opin Plant Biol. 2006;9:122-7.

Turlings TCJ, Alborn HT, Loughrin JH, Tumlinson JH. Volicitin, an elicitor of maize volatiles in oral secretion of Spodoptera exigua: isolation and bioactivity. J Chem Ecol. 2000;26:189-202.

Urbanczyk-Wochniak E, Sumner LW. MedicCyc: A biochemical pathway database for Medicago truncatula. Bioinformatics 2007;23:1418-23.

van Dam NM, van der Meijden E, Verpoorte R. Induced responses in three alkaloid-containing plant species. Oecologia 1993;95:425-30.

van der Fits L, Memelink J. ORCA3, a jasmonate-responsive transcriptional regulator of plant primary and secondary metabolism. Science 2000;289:295-7.

Voelckel C, Baldwin IT. Detecting herbivore-specific transcriptional responses in plants with multiple DDRT-PCR and subtractive library procedures. Physiologia Plantarum 2003;118:240-52.

von Dahl CC, Hävecker M, Schlögl R, Baldwin IT. Caterpillar-elicited methanol emission: a new signal in plant-herbivore interactions. The Plant J 2006;46:948-60.

von Dahl CC, Winz RA, Halitschke R, Kühnemann F, Gase K, Baldwin IT. Tuning the herbivore-induced ethylene burst: the role of transcript accumulation and ethylene perception in Nicotiana attenuata. The Plant J 2007;51:293-307.

Walling LL. The myriad of plant responses to herbivore. J Plant Growth Regul. 2000;19:195-216. 
Wolucka BA, Goossens A, Inzé D. Methyl jasmonate stimulates the de novo biosynthesis of vitamin C in plant cell suspensions. J Exp Bot. 2005;56:2527-38.

Xiong L, Lee H, Ishitani M, Zhu J-K. Regulation of osmotic stress-responsive gene expression by the LOS6/ABA1 locus in Arabidopsis. The J Biol Chem. 2002;277:8588-96.

$\mathrm{Xu}$ L, Liu F, Lechner E, Genschik P, Crosby WL, Ma H, et al. The SCFCOI1 ubiquitin-ligase complexes are required for jasmonate response in Arabidopsis. Plant Cell. 2002;14:1919-35.

Yazaki K. ABC transporters involved in the transport of plant secondary metabolites. FEBS. 2006;580:1183-91.

Zangerl AR, Hamilton JP, Miller TJ, Crofts AR, Oxborough K, Berenbaum MR, DeLucia EH. Impact of folivory on photosynthesis is greater than the sum of its holes. Proc Natl Acad Sci 2002;99:1088-91.

Zhang N, Kallis RP, Ewy RG, Portis AR Jr. Light modulation of Rubisco in Arabidopsis requires a capacity for redox regulation of the larger Rubisco activase isoform. Proc Natl Acad Sci. 2002;99:3330-4.

Zhu-Salzman K, Bi J-L, Liu T-X. Molecular strategies of plant defense and insect counter-defense. Insect Sci. 2005;21:3-15. 